\title{
Abdominal gunshot wound in a pregnant woman: a different view to a case report
}

\author{
K. Emre Karaşahin \\ Department of Obstetrics and Gynecology, Gülhane Military Medicine Academy, Ankara, Turkey
}

I have read the manuscript of Kocamer et al. entitled as "Abdominal gunshot wound in pregnant woman: a case report" ${ }^{\text {"[1] }}$ with great interest. I would like to thank the authors for their efforts in the study and for sharing it with us.

In this critical case, it is pleasing to save both the mother and the baby by the immediate intervention.

Although it was stated in the case report that there was single bullet entrance hole in the lower abdominal region but no other abdominal injury and there was no intraabdominal organ damage, it was not stated whether any material (cartridge bullet or shell fragment) as the reason for injury was removed or not. Also, although it was reported that there was penetrant injury on left corpus over uterus and that the fetus was injured from the foot (entrance and exit) as a result of this gunshot, no exit hole of cartridge bullet or shell fragment from uterus was mentioned. No information was provided about the exit hole from the body.

It is known that the patient underwent immediate laparotomy under emergency cases but it was not reported if there was any intraoperative radiologic evaluation for locating cartridge bullet. On the other hand, locating cartridge bullet/fragments and completing the treatment is very important in terms of both prognosis and medicolegal problems (judicial reports).

When there is an entrance hole, it is required to investigate the abdomen radiologically (by direct graphy or CT if possible) and to locate exit hole if no bullet or fragment was found.
If cartridge bullet/fragments did not leave uterus (or body), it will be an appropriate approach to remove these materials (if possible surgically) and to deliver to prosecution office for ballistics. Metal parts should certainly be handled by plastic gloves and removed by forceps wrapped with gauze bandages as not preventing ballistic investigation due to additional marks and deformation on metal. ${ }^{[2]}$ For the parts impossible to remove due to its position should be stated in the judicial report.

Prophylactic antibiotics ${ }^{[3]}$ are recommended for gunshot injuries; evaluation and vaccination should be considered in terms of tetanus, and evaluation and Anti-D immunoglobulin if necessary should be considered in terms of isoimmunisation for pregnant women.

Due to the increase in terrorist actions and violence against women, the possibility that obstetricians encounter gunshot injuries tends to increase.

Gündoğmuş et al. reports that "In the injury offences against pregnant women, both maternal and fetal vital functions and the impacts of damages on the life quality are significant in terms of cause and effect relation." ${ }^{[[]]}$ and "The efforts made by the physicians from various departments, who intervene in such cases and undertake their treatments and follow-ups later, in defining the presence and characteristics of clinic and traumatic findings in detail are the most significant factor for realizing the principle of justice in today's law."

I believe that preparing surgery reports in gunshot injuries, writing all physical, radiological and laboratory
Correspondence: K. Emre Karaşahin, MD. Gülhane Askeri Tip Akademisi Kadın Hastalıkları ve Doğum Anabilim Dalı, Turkey.

e-mail: dremrekarasahin@gmail.com

Received: August 17, 2014; Accepted: September 15, 2014
Available online at: www.perinataljournal.com/20140223013 doi:10.2399/prn.14.0223013 QR (Quick Response) Code: 
findings and evidencing all factors causing the injury are very important medicolegally in terms of the victim, perpetrator and intervening physicians.

Conflicts of Interest: No conflicts declared.

\section{Kaynaklar}

1. Kocamer B, Gökçe ON, Aksoy A, Deniz İB. Abdominal gunshot wound in pregnant woman: a case report. Perinatal Journal 2014;22:110-13.
2. Marx JA, Hockberger RS, Walls RM. Rosen's emergency medicine. Concepts and clinical practice. 8th Ed. St. Louis: Mosby; 2006. Chapter 65, p. 828-844.e2

3. Puskarich MA. Initial evaluation and management of abdominal gunshot wounds in adults. In: UpToDate Editor: Moreira ME, Grayzel J (accessed at 15 th August 2014).

4. Gündoğmuş UN, Akkaya H, Karbeyaz K, Keskin A. Residual pellet in fetal brain tissue following a gunshot injury to a pregnant woman: a case report. Ulus Travma Acil Cerrahi Derg 2013;19:371-4. 